The ulcer crater disappeared completely in $81 \%$ of the cases after six weeks and in $92 \%$ after 12 weeks of carbenoxolone.

The dose used in the trial was $100 \mathrm{mg}$. thrice daily for the first week and $50 \mathrm{mg}$. thrice daily for the second and subsequent weeks. Treatment should be continued until the ulcer has been shown radiologically to have healed. After complete healing a maintenance dose should be prescribed to prevent recurrence.

Attention is also drawn to the drug's side-effects, which occurred in $35 \%$ of patients, and of which salt-and-water retention is the most important. The side-effects led to the introduction of a five- or six-day regime in which carbenoxolone was omitted on one or both days at the week-end in those at risk. Since the introduction of this regime side-effects have been much less marked and less frequent.

Carbenoxolone has a specific effect, facilitating the healing of gastric ulcer, and is not merely yet another symptomatic measure.

We are grateful to the physicians of Whiston Hospital for their help and for allowing us to treat patients under their care; to
Dr. S. Gottfried for his assistance; to Biorex Laboratories Ltd. for supplies of trial tablets and carbenoxolone sodium; to Mr. F. M. Sullivan, of Guy's Hospital Medical School, for his assistance with the statistical analysis; and to Mr. E. Thomas, Chief Pharmacist, Whiston Hospital, who distributed the trial tablets.

\section{REFERENCES}

Brøchner-Mortensen, K., Krarup, N. B., Meulengracht, E., Videbrek, A. (1955). Brit. med. $\} ., 1,818$.

Doll, R., Hill, I. D., Hutton, C., and Underwood, D. J. (1962). Lancet, $2,793$.

Jones, F. A., and Pygott, F. (1958). Ibid., 1, 657.

Price, A. V., Pygott, F., and Sanderson, P. H. (1956). Ibid., 1, 70. and Pygott, F. (1952). Ibid., 1, 171.

Johnson, H. D., Love, A. H. G., Rogers, N. C., and Wyatt, A. P. (1964). Gut, 5,402 .

Malmros, H., and Hiertonn, T. (1949). Acta med. scand., 133, 229.

Malmros, H., and Hiertonn, T. (1949). Acta med.

Parke, D. V. (1964). Personal communication.

Parke, D. V. (1964). Personal (1946). Acta med. scand., 126, 34.

Revers, F. E. (1946). Ned. T. Geneesk., 90, 135.

Swynnerton, B. F., and Tanner, N. C. (1953). Brit. med. F., 2, 841. Tarnoky, A. L. (1964). Personal communication.

\title{
Clinical Comparison of Frusemide with Bendrofluazide, Mersalyl, and Ethacrynic Acid
}

\author{
J. H. STEWART,* M.R.C.P., M.R.A.C.P. ; K. D. G. EDWARDS,* M.D., B.S., M.R.A.C.P.
}

Brit. med. F., 1965, 2, 1277-1281

Frusemide (4 - chloro - $N$ - (2 - furylmethyl) - 5 - sulphamoyl anthranilic acid; Lasix) is a newly introduced diuretic agent which differs from all other such drugs at present in clinical use. Though a sulphonamide derivative (see Formula), frusemide does not closely resemble chlorthalidone or the benzothiadiazine drugs chemically or pharmacologically (Stewart, 1965). Frusemide may be given orally or parenterally; by either route it produces a rapid, short-lived diuresis due to inhibition of salt-and-water reabsorption in both proximal and distal portions of the renal tubule (Suzuki, Klütsch, and Heidland, 1964).<smiles>COS(=O)(=O)c1cc(C(=O)O)c(NCc2ccco2)cc1Cl</smiles>

Several clinical trials in oedematous patients have shown that frusemide causes a greater natriuresis than other commonly used diuretic drugs. In doses ranging from 25 to $100 \mathrm{mg}$. it is superior to an equal dose of hydrochlorothiazide (Kleinfelder, 1963 ; Stokes and Nunn, 1964 ; Verel, Stentiford, Rahman, and Saynor, 1964). Stokes and Nunn (1964) found that $50 \mathrm{mg}$. of frusemide was more potent than $5 \mathrm{mg}$. of bendrofluazide or $200 \mathrm{mg}$. of chlorthalidone, and Verel et al. (1964) that $80 \mathrm{mg}$. of frusemide was more potent than mersalyl $2 \mathrm{ml}$., triamterene $200 \mathrm{mg}$., cyclopenthiazide $1 \mathrm{mg}$, , or chlorthalidone $200 \mathrm{mg}$. Rosenkranz (1964) obtained a greater natriuretic response to frusemide, $1 \mathrm{mg}$. $/ \mathrm{kg}$./day, than to 10 times this dose of acetazolamide.

- From the Renal Unit, Kanematsu Memorial Institute, Sydney Hospital, Sydney, Australia.
In the present trial frusemide was compared with ethacrynic acid, a very potent new diuretic, and with representative examples of the two commonly used types of diuretic drug, a benzothiadiazine and an organic mercurial. Frusemide was more efficacious than the benzothiadiazine or mercurial, and, in relation to natriuretic activity, caused little excess potassium loss.

\section{Clinical Material and Methods}

Eleven patients were studied. Each had been admitted to hospital for the treatment of oedema which had failed to improve with ordinary diuretic therapy. Relevant clinical data on these patients are shown in Table I. Of the 11 patients, one had portal hypertension, two had the nephrotic syndrome, and eight had congestive heart failure due to various causes. All but four patients had some impairment of renal function.

Each patient was weighed daily at 8 a.m., and accurate 8 a.m. to 8 a.m. fluid-balance charts were kept. The volume and sodium, potassium, and chloride content of each 24-hour collection of urine were measured. Serum and urinary electrolytes and serum urea nitrogen concentrations were determined on the Technicon AutoAnalyzer, and creatinine was measured by the method of Edwards and Whyte (1958).

\section{Design of Clinical Trials}

All patients were given a diet containing $3 \mathrm{~g}$. of salt (approximately $50 \mathrm{mEq}$ of $\mathrm{Na}$ ) and allowed 1 litre of drinking-fluids each day. The diuretic drugs were given daily at $10 \mathrm{a.m}$. in a single oral dose unless otherwise stated, except spironolactone, which was given in four equal doses daily. In trials $A, B$, and $\mathrm{C}$ only one diuretic drug was given each day.

Trial A.-Three patients were given each of four different treatments in two-day periods for 32 days. The treatments 
TABle I.-Clinical Data of Patients in Frusemide Trial

\begin{tabular}{|c|c|c|c|c|c|c|c|}
\hline \multirow{2}{*}{$\begin{array}{l}\text { Case } \\
\text { No. }\end{array}$} & \multirow{2}{*}{ Sex } & \multirow{2}{*}{ Age } & \multirow{2}{*}{ Diagnosis } & \multirow{2}{*}{ Renal Function } & \multirow{2}{*}{$\begin{array}{c}\text { Serum } \\
\text { Albumin } \\
\text { (g. } / 100 \mathrm{ml} .)\end{array}$} & \multicolumn{2}{|c|}{ Previous Diuretic Therapy } \\
\hline & & & & & & Drug & Result \\
\hline 1 & $M$ & 51 & Aortic incompetence & $\begin{array}{l}\text { Serum creatinine } 0.88 \mathrm{mg} . / 100 \\
\mathrm{ml} \text {. }\end{array}$ & $2 \cdot 7$ & Bendrofluazide. Spironolactone & Moderate oedema worsening \\
\hline $\begin{array}{l}2 \\
3\end{array}$ & $\underset{F}{F}$ & $\begin{array}{l}64 \\
68\end{array}$ & $\begin{array}{l}\text { Mitral stenosis } \\
\text { Portal vein thrombosis. Is- } \\
\text { chaemic heart disease (mild) }\end{array}$ & $\begin{array}{l}\text { Crcat. clearance } 44 \mathrm{ml} . / \mathrm{min} \text {. } \\
\text { Creat. clearance } 40 \mathrm{ml} . / \mathrm{min} \text {. }\end{array}$ & $\begin{array}{l}3 \cdot 6 \\
2 \cdot 8\end{array}$ & $\begin{array}{l}\text { Spironolactone. Triamterene } \\
\text { Mersalyl. Ethacrynic acid. } \\
\text { Spironolactone }\end{array}$ & $\begin{array}{l}\text { Severe oedema unrelieved. } \\
\text { Moderate oedema unrelieved. }\end{array}$ \\
\hline 4 & $\begin{array}{l}M \\
M\end{array}$ & $\begin{array}{l}38 \\
36\end{array}$ & $\begin{array}{l}\text { Alcoholic cardiomyopathy. } \\
\text { Hepatic cirrhosis (mild) } \\
\text { Alcoholic cardiomyopathy. } \\
\text { Hepatic cirrhosis (mild) }\end{array}$ & $\begin{array}{l}\text { Creat. clearance } 202 \mathrm{ml} . / \mathrm{min} \text {. } \\
\text { Creat. clearance } 65 \mathrm{ml} . / \mathrm{min} \text {. }\end{array}$ & $\begin{array}{l}2 \cdot 9 \\
3 \cdot 6\end{array}$ & $\begin{array}{c}\text { Chlorothizide. Spironolac- } \\
\text { tone. Peritoneal dialysis }\end{array}$ & $\begin{array}{l}\text { Gross oedema unrelieved. } \\
\text { Marked improvement. } \\
\text { Moderate oedema worsening }\end{array}$ \\
\hline $\begin{array}{l}6 \\
7\end{array}$ & $\begin{array}{l}M \\
M\end{array}$ & $\begin{array}{l}76 \\
36\end{array}$ & $\begin{array}{l}\text { Ischaemic heart disease } \\
\text { Primary nephrotic syndrome } \\
\text { ("minimal change" glome- } \\
\text { rular lesion) }\end{array}$ & $\begin{array}{l}\text { Serum urea } 49-32 \mathrm{mg} . / 100 \mathrm{ml} \text {. } \\
\text { Creat. clearance } 76 \mathrm{ml} / \mathrm{min} \text {. }\end{array}$ & $\begin{array}{l}3 \cdot 6 \\
1 \cdot 0\end{array}$ & Mersalyl. Bendrofluazide & $\begin{array}{l}\text { Severe oedema worsening } \\
\text { Severe oedema with oliguria }\end{array}$ \\
\hline $\begin{array}{l}8 \\
9\end{array}$ & $\stackrel{M}{M}$ & $\begin{array}{l}60 \\
57\end{array}$ & $\begin{array}{l}\text { Ischaemic heart disease } \\
\text { Ischaemic heart disease }\end{array}$ & $\begin{array}{l}\text { S. creat. } 1 \cdot 19 \mathrm{mg} . / 100 \mathrm{ml} \text {. } \\
\text { S. urea } 141-64 \mathrm{mg} . / 100 \mathrm{ml} \text {. }\end{array}$ & $\begin{array}{l}3 \cdot 8 \\
3 \cdot 0\end{array}$ & $\begin{array}{l}\text { Mersalyl. Chlorothiazide } \\
\text { Mercaptomerin. Chlorthali- } \\
\text { done. Spironolactone }\end{array}$ & $\begin{array}{l}\text { Severe oedema with ascites } \\
\text { Severe oedema with increasing } \\
\text { ascites }\end{array}$ \\
\hline 10 & $\mathrm{~F}$ & 44 & $\begin{array}{l}\text { Membranous glomerulone- } \\
\text { phritis }\end{array}$ & S. urea $182-99 \mathrm{mg} . / 100 \mathrm{ml}$. & $1 \cdot 8$ & Peritoneal dialysis & $\begin{array}{l}\text { Moderate oedema temporarily } \\
\text { relieved }\end{array}$ \\
\hline 11 & M & 65 & $\begin{array}{c}\text { Cor pulmonale. Ischaemic } \\
\text { heart disease }\end{array}$ & S. urea $58-49 \mathrm{mg} . / 100 \mathrm{ml}$. & $3 \cdot 4$ & - & Moderate oedema worsening \\
\hline
\end{tabular}

were: (1) no diuretic, (2) bendrofluazide $10 \mathrm{mg}$., (3) ethacrynic acid $100 \mathrm{mg}$., (4) frusemide $80 \mathrm{mg}$., daily. The order of the treatment periods was randomized by means of the principles elaborated by Gold, Kwit, Messeloff, Kramer, Golfins, Greiner, Goessel, Hughes, and Warshaw (1960), as illustrated for Case 1 in Fig. 1. For Cases 2 and 3 the order of administering the
Trial C.-Two patients were given no diuretic drug, or frusemide $200 \mathrm{mg}$. orally, or mersalyl $2 \mathrm{ml}$. intramuscularly, over a period of six days, in the order OABBAO, as illustrated for Case 6 in Fig. 3. The order of giving the drugs was reversed for Case 7. At the time of receiving the mersalyl Case 6 had a serum chloride concentration of $97 \mathrm{mEq} / 1$, and a serum
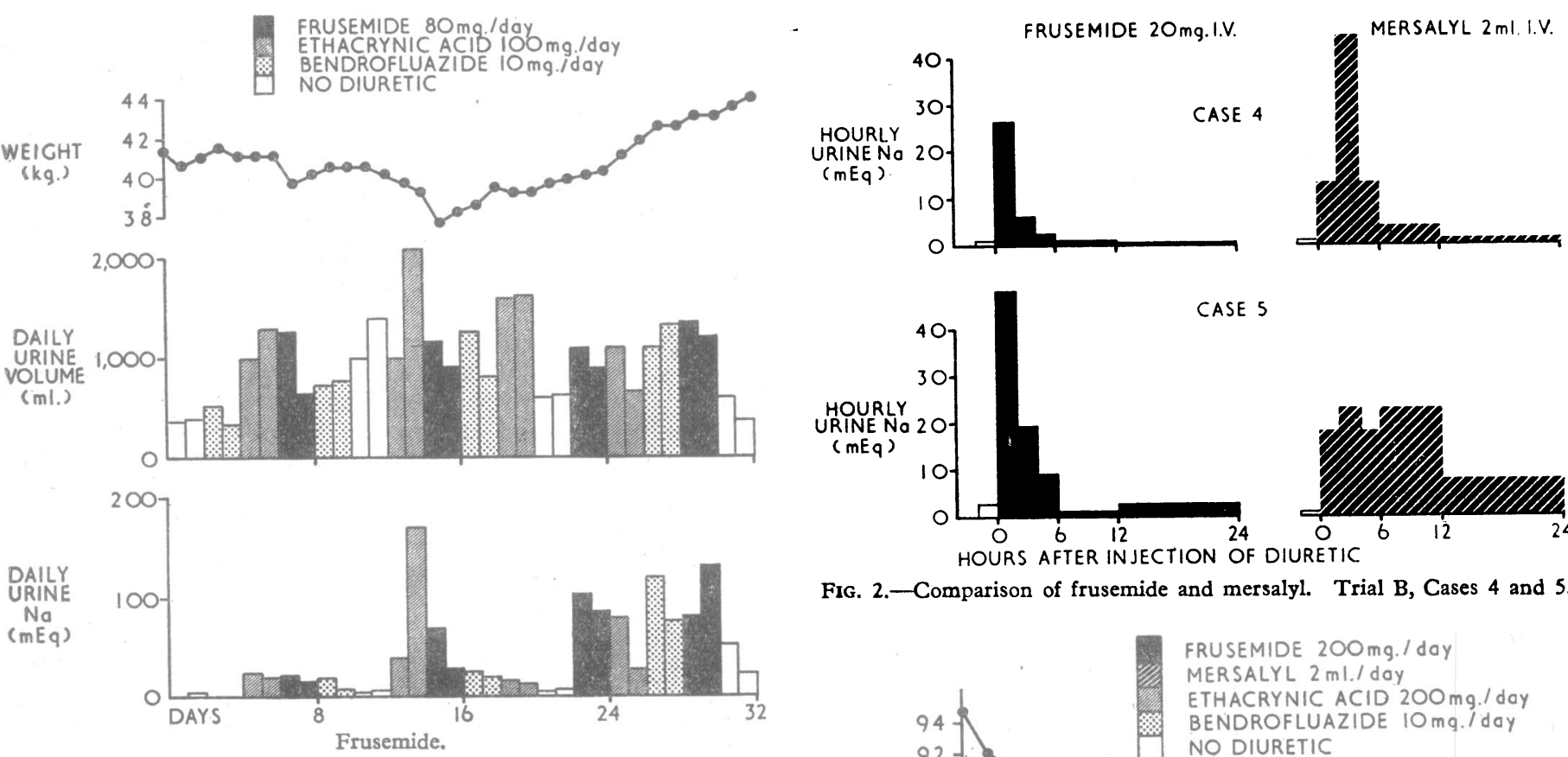

Fig. 1.- Comparison of frusemide, ethacrynic acid, and bendrofluazide. Trial A, Case 1.

drugs was interchanged. Oral supplements of potassium citrate or gluconate, $60 \mathrm{mEq} /$ day, were given to each patient constantly throughout the trial. The results of trial A were subjected to a statistical analysis of variance in order to eliminate three variable factors: (1) "within-patient" variations in diuretic responsiveness; (2) " between-patient" variations in diuretic responsiveness; and (3) carry-over effect of the diuretic drug given on the preceding day. The differences between each treatment were then tested for significance.

Trial B.-Two patients (Cases 4 and 5) were each given frusemide $20 \mathrm{mg}$. intravenously, and, a week earlier or later, mersalyl $2 \mathrm{ml}$. by the same route. Urine was collected for 2 hours before injection, and at 2, 4, 6, 12, and 24 hours after the injection as illustrated in Fig. 2. At the time of receiving the mersalyl injection Case 4 had a serum chloride concentration of $84 \mathrm{mEq} / \mathrm{l}$, and a serum carbon-dioxide combining power of $32 \mathrm{mEq} / 1$., and Case 5 had levels of 101 and $28 \mathrm{mEq} /$ 1. respectively.

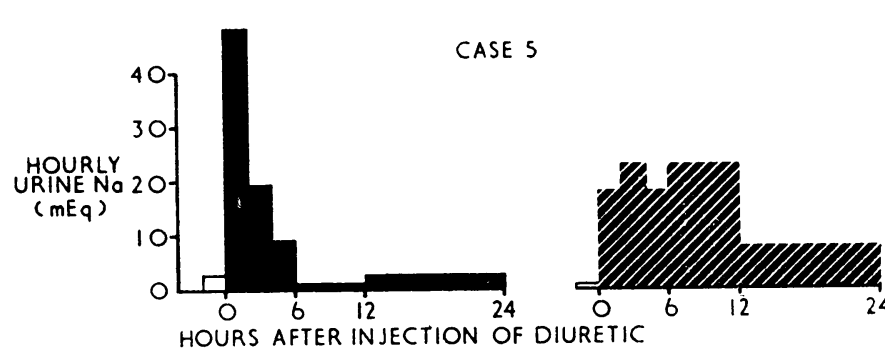

FIG. 2.-Comparison of frusemide and mersalyl. Trial B, Cases 4 and 5 .

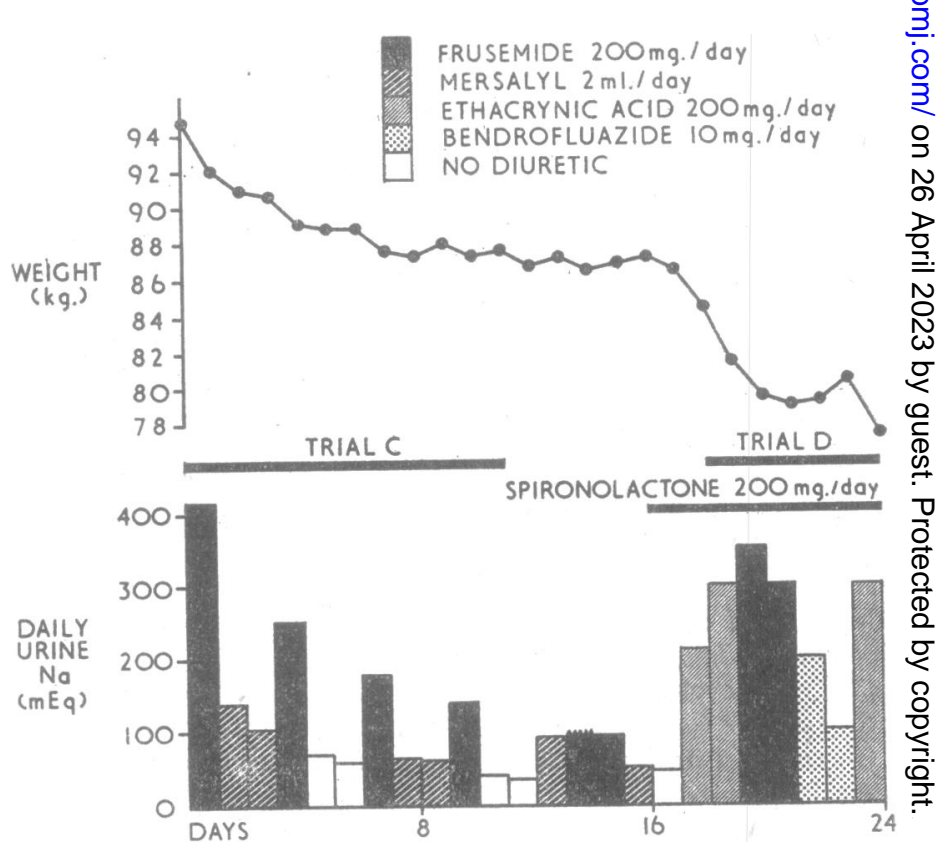

FIG. 3.-Comparison of frusemide, morsalyl, ethacrynic acid, and bendrofluazide. Trials $C$ and D, Case 6. 
carbon-dioxide combining power of $29 \mathrm{mEq} / \mathrm{l}$, and Case 7 levels of 103 and $27 \mathrm{mEq} / 1$. respectively.

Trial D.-Three patients were given spironolactone (Aldactone-A) $200 \mathrm{mg}$. daily, and, in addition, bendrofluazide $10 \mathrm{mg}$., ethacrynic acid $200 \mathrm{mg}$., or frusemide $200 \mathrm{mg}$. orally as illustrated for Case 6 in Fig. 3. The results from the first two days of spironolactone treatment were omitted from the trial.

Trial E.-Six patients were treated with frusemide in two or more different doses. The scheme of dose rotation was variable, but the ABBA plan was closely followed. Three of the patients were also given other diuretic drugs at a constant dose throughout the trial (see Table V).

\section{Results}

The natriuretic potency of frusemide (Table II ; Figs. 1, 2, and 3) was approximately the same as that of ethacrynic acid when the two drugs were given in equal doses by weight, but $80 \mathrm{mg}$. of frusemide was more than twice as potent as $10 \mathrm{mg}$. of bendrofluazide. Mersalyl, $2 \mathrm{ml}$., was intermediate in potency between 20 and $200 \mathrm{mg}$. of frusemide.

TABLB II.-Urinary Sodium Excretion after Frusemide or Other Diuretics

\begin{tabular}{|c|c|c|c|c|c|c|c|}
\hline \multirow[b]{2}{*}{ Trial } & \multirow{2}{*}{$\begin{array}{l}\text { No. of } \\
\text { Days per } \\
\text { Treatment }\end{array}$} & \multirow[b]{2}{*}{$\begin{array}{l}\text { Case } \\
\text { No. }\end{array}$} & \multicolumn{5}{|c|}{ Urinary $\mathrm{Na}$ (mean, $\mathrm{mEq} / 24 \mathrm{hr}$.) } \\
\hline & & & $\begin{array}{c}\text { No } \\
\text { Diuretic }\end{array}$ & $\begin{array}{l}\text { Bendro- } \\
\text { fluazide }\end{array}$ & $\begin{array}{l}\text { Etha- } \\
\text { crynic } \\
\text {. Acid }\end{array}$ & $\begin{array}{c}\text { Fruse- } \\
\text { mide }\end{array}$ & $\begin{array}{c}\text { Mers- } \\
\text { alyl }\end{array}$ \\
\hline \multirow{3}{*}{$\begin{array}{l}A^{*} \\
\mathbf{B}\end{array}$} & \multirow[t]{2}{*}{$\begin{array}{l}8 \\
8 \\
8\end{array}$} & $\begin{array}{l}1 \\
2 \\
3\end{array}$ & $\begin{array}{c}11 \\
4 \\
16\end{array}$ & $\begin{array}{r}32 \\
7 \\
33\end{array}$ & $\begin{array}{l}48 \\
42 \\
96\end{array}$ & $\begin{array}{l}65 \\
37 \\
59\end{array}$ & \\
\hline & & Mean & 11 & 26 & 64 & 54 & \\
\hline & $\frac{1}{1}$ & & $\begin{array}{l}10 \\
43\end{array}$ & & & $\begin{array}{r}77 \\
195\end{array}$ & $\begin{array}{l}176 \\
350 .\end{array}$ \\
\hline C & $\begin{array}{l}2 \\
2 \\
2\end{array}$ & $6\left\{\begin{array}{l}\text { (i) } \\
7\end{array}\right.$ & $\begin{array}{r}79 \\
48 \\
1\end{array}$ & & & $\begin{array}{r}337 \\
162 \\
50\end{array}$ & $\begin{array}{r}127 \\
68 \\
22\end{array}$ \\
\hline $\mathbf{D}$ & $\begin{array}{l}2 \\
2 \\
4\end{array}$ & $\begin{array}{l}6 \\
7 \\
8\end{array}$ & $\overline{4}$ & $\frac{155}{95}$ & $\begin{array}{r}306 \\
12\end{array}$ & $\begin{array}{r}329 \\
16 \\
146\end{array}$ & \\
\hline
\end{tabular}

- Significance of differences between treatments in trial A:

Ethacrynic acid $v$. frusemide $0.1<P$

Bendrofluazide $v$. no diuretic $0.001<P<0.01$

All other pairs of treatments $\mathrm{P}<0.001$.

With few exceptions potassium excretion (Table III) was increased over control values by all diuretic drugs other than mersalyl. Potassium loss was related to natriuretic efficacy by determining the urinary sodium/potassium ratio (Table III). In trial $\mathrm{A}$, in which the results were statistically significant, frusemide and ethacrynic acid caused the least mean potassium loss and the highest mean urinary sodium/potassium ratio, and bendrofluazide the greatest mean potassium loss and lowest mean urinary sodium/potassium ratio. In trials $B$ and $C$ the urinary potassium excretion after mersalyl was less than that after frusemide, but the sodium/potassium ratios were not significantly different.

In trial $\mathrm{A}$ weight change and daily urine volume were altered by the different diuretic drugs in much the same manner as was urinary sodium loss (Table IV). An exception was the proportionately greater weight loss after ethacrynic acid than after the other treatments. The urinary excretion of chloride was increased by a greater amount than that of sodium by each of the treatments, particularly by ethacrynic acid, and the excretion of anions other than chloride (determined approximately from urinary $\mathrm{Na}+\mathrm{K}-\mathrm{Cl}$ ) was lower after frusemide or ethacrynic acid than in the control period, but higher after bendrofluazide (Table IV).

TABLB IV.-Weight Change, and Urinary Volume, Chloride, and Other Anion Excretion after Frusemide or Other Diuretics (Trial A)

\begin{tabular}{|c|c|c|c|c|}
\hline & \multicolumn{4}{|c|}{ Mean 24-hr. Values } \\
\hline & $\begin{array}{c}\text { No } \\
\text { Diuretic }\end{array}$ & $\begin{array}{l}\text { Bendro- } \\
\text { fluazide }\end{array}$ & $\begin{array}{l}\text { Ethacrynic } \\
\text { Acid }\end{array}$ & Frusemide \\
\hline \multirow[t]{2}{*}{ 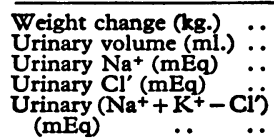 } & $\begin{array}{c}0.15 \text { (gain) } \\
900 \\
11 \\
8\end{array}$ & $\begin{array}{c}+0 \cdot 11 \text { (gain) } \\
1,174 \\
26 \\
34\end{array}$ & $\begin{array}{c}-0.33 \text { (lo88) } \\
1,530 \\
64 \\
86\end{array}$ & \begin{tabular}{|c|}
-0.04 (1088) \\
1,404 \\
54 \\
64
\end{tabular} \\
\hline & 72 & 89 & 62 & 65 \\
\hline
\end{tabular}

The exhibition of frusemide to a patient already taking spironolactone increased urinary sodium excretion (trial $D$, Case 8), and the response to frusemide could be improved by adding spironolactone to the treatment (Fig. 3). In trial $\mathbf{E}$, increasing the dose of frusemide within the range from 40 to $240 \mathrm{mg}$. (Table V) caused an approximately linear increase in sodium excretion in the diuretic responsive patients (Cases 1, 11 , and 4), but there was much less change in the diuretic resistant patients (Cases 9, 10, and 2).

TABLB V.-Effect on Urinary Sodium Excretion of Varying Dose of

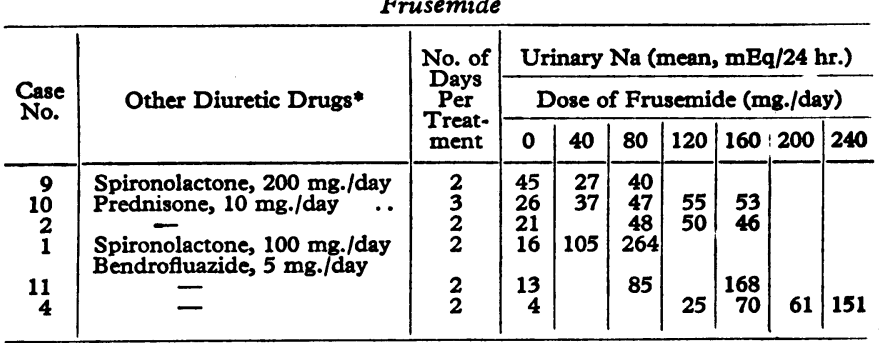

* These drugs were given unchanged every day throughout the trial.

\begin{tabular}{|c|c|c|c|c|c|c|c|c|c|c|c|}
\hline \multirow{3}{*}{ Trial } & \multirow{3}{*}{ Case No. } & \multicolumn{10}{|c|}{ Urinary $\mathrm{K}$ and $\mathrm{Na} / \mathrm{K}$ Ratio (mean, $\mathrm{mEq} / 24 \mathrm{hr}$.) } \\
\hline & & \multicolumn{2}{|c|}{ No Diuretic } & \multicolumn{2}{|c|}{ Bendrofluazide } & \multicolumn{2}{|c|}{ Ethacrynic Acid } & \multicolumn{2}{|c|}{ Frusemide } & \multicolumn{2}{|c|}{ Mersalyl } \\
\hline & & $\mathbf{K}$ & $\mathrm{Na} / \mathrm{K}$ & $\mathbf{K}$ & $\mathrm{Na} / \mathrm{K}$ & $\mathbf{K}$ & $\mathrm{Na} / \mathrm{K}$ & $\mathbf{K}$ & $\mathrm{Na} / \mathrm{K}$ & $\mathbf{K}$ & $\mathrm{Na} / \mathrm{K}$ \\
\hline \multirow[t]{2}{*}{$\mathbf{A}^{*}$} & $\begin{array}{l}1 \\
2 \\
3\end{array}$ & $\begin{array}{l}83 \\
41 \\
84\end{array}$ & $\begin{array}{l}0.1 \\
0.1 \\
0.2\end{array}$ & $\begin{array}{r}85 \\
55 \\
156\end{array}$ & $\begin{array}{l}0.3 \\
0.1 \\
0.2\end{array}$ & $\begin{array}{r}81 \\
46 \\
133\end{array}$ & $\begin{array}{l}0.6 \\
0.9 \\
0.7\end{array}$ & $\begin{array}{l}80 \\
48 \\
97\end{array}$ & $\begin{array}{l}0.8 \\
1.0 \\
0.6\end{array}$ & & \\
\hline & Mean & 69 & $0 \cdot 19$ & 95 & 0.21 & 87 & 0.77 & 77 & 0.87 & & \\
\hline $\begin{array}{l}\text { B } \\
\text { C }\end{array}$ & 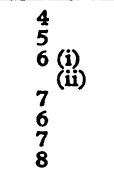 & $\begin{array}{l}70 \\
26 \\
52 \\
56 \\
22 \\
\frac{7}{29}\end{array}$ & $\begin{array}{l}0.1 \\
1.6 \\
1.5 \\
0.9 \\
0.0 \\
\frac{1}{1.5}\end{array}$ & $\frac{131}{97}$ & $\frac{1.2}{1.0}$ & $\begin{array}{r}117 \\
61\end{array}$ & $\begin{array}{l}3.2 \\
0.2\end{array}$ & $\begin{array}{r}88 \\
34 \\
91 \\
66 \\
53 \\
125 \\
58 \\
47\end{array}$ & $\begin{array}{l}0.9 \\
5.0 \\
3.7 \\
2.3 \\
0.8 \\
2.7 \\
0.3 \\
3.1\end{array}$ & $\begin{array}{l}34 \\
17 \\
41 \\
48 \\
41\end{array}$ & $\begin{array}{r}5.2 \\
20.6 \\
31 . \\
1.4 \\
0.5\end{array}$ \\
\hline
\end{tabular}

* Significance of differences between treatments in trial A:

For urinary $\mathrm{K}^{+}$

no diuretic $v$. bendrofluazide

no diuretic $v$. ethacrynic acid

frusemide $v$. bendrofluazide

\} $0.01<P<0.05$

For urinary $\mathrm{Na} / \mathrm{K}$ : all patments $\ldots .1<\mathrm{P}$ 


\section{Discussion}

The results show that frusemide is a highly potent saluretic agent. The efficacy of frusemide, and, to a lesser extent, of ethacrynic acid, was underestimated in comparison with bendrofluazide and mersalyl, for the latter two drugs were given in maximally effective doses for oedematous subjects (Swartz, Seller, Fuchs, Brest, and Moyer, 1963 ; Clarke, Modell, Greiner, Kwit, Gluck, and Gold, 1950). In non-oedematous subjects the maximally effective dose of frusemide is rather more than 150 mg. (Timmerman, Springman, and Thoms, 1964), and that of ethacrynic acid is $200 \mathrm{mg}$. (Melvin, Farrelly, and North, 1963), but in diuretic-responsive oedematous patients the maximally effective dose of these two drugs may well be higher, as suggested for ethacrynic acid in our own pilot study, by Foltz (1963), and by Maher, O'Connell, Setter, and Schreiner (1964), and for frusemide by the results of trial E. Moreover, frusemide has a duration of action of only four hours (Fig. 2), whereas that of ethacrynic acid (Melvin et al., 1963), bendrofluazide (Ford and Nickell, 1960), and mersalyl (Fig. 2) is about 12 hours. In theory frusemide in maximally effective doses could be repeated much more frequently than the other drugs, but in practice a single $80-200-\mathrm{mg}$. dose of frusemide caused as much fluid loss as our rather ill patients could tolerate.

Three patients (Cases 9, 10, and 2 in trial E) responded poorly to frusemide, presumably because of moderate renal impairment (Table I). Non-oedematous patients with renal impairment, when given frusemide (Heidland, Klütsch, and Suzuki, 1964 ; Vorburger, 1964) or chlorothiazide or meralluride (Reubi and Cottier, 1961), responded by increasing urinary sodium excretion by an amount proportional to the glomerular filtration rate. With each of these drugs a detectable natriuresis was obtained in all patients whose glomerular filtration rate was more than $10 \mathrm{ml} . / \mathrm{min}$., but the response to frusemide was greater than that to the other drugs. Since the response to frusemide of patients with renal impairment is improved by raising the dose (Heidland et al., 1964), it would be reasonable to use larger doses-for example, $200-400 \mathrm{mg}$./ day-when conventional doses prove inadequate in these circumstances. Ethacrynic acid caused a diuresis in nearly all oedematous patients with renal disease and glomerular filtration rates as low as $6 \mathrm{ml} . / \mathrm{min}$. (unpublished observations on patients reported by Edwards, Sinnett, and Stewart, 1964). Patients with gross oedema sometimes responded poorly or transiently to frusemide, but when the oedema was not associated with renal circulatory impairment or intrinsic renal disease diuresis was usually induced by giving spironolactone in addition to frusemide.

Frusemide resembles ethacrynic acid and mersalyl in that it causes little increase in the excretion of potassium or of anions other than chloride as determined by $(\mathrm{Na}+\mathrm{K}-\mathrm{Cl})$. Though the dietary content of minerals and protein was not strictly controlled, the design of trial $\mathrm{A}$, by intermingling the treatments, would have eliminated the error due to any fluctuations in food intake. In this trial, in which there were many randomized treatment periods, it is probable that variations in the day-today excretion of non-buffer ions-for example, $\mathrm{Ca}++, \mathrm{Mg}^{++}$, and $\mathrm{SO}_{4}{ }^{\prime \prime}$-were equally distributed between the different treatments, and that most of the between-treatment differences in urinary $(\mathrm{Na}+\mathrm{K}-\mathrm{Cl})$ were due to the effect of the diuretic drugs on the excretion of buffer anions, particularly bicarbonate and/or of hydrogen and ammonium ions. The conclusion from these results that frusemide causes less net excretion of base than does bendrofluazide accords with the demonstration in vitro that frusemide does not inhibit carbonic anhydrase (Muschaweck and Hajdú, 1964). Though there are no published reports describing either presence or absence of in vitro inhibition of carbonic anhydrase by ethacrynic acid, the extensive clinical investigation of this drug undertaken by Cannon, Ames, and Laragh (1963) leaves little doubt that ethacrynic acid has no significant inhibitory effect on carbonic anhydrase. The excess excretion of chloride over that of sodium and potassium resulting from the administration of ethacrynic acid, and to a lesser extent of frusemide, may induce hypochloraemic alkalosis when these drugs are given for long periods. Few patients, except those with hepatic cirrhosis, require supplementary potassium therapy while taking frusemide (Kleinfelder, 1963 ; Stokes and Nunn, 1964 ; Vorburger, 1964).

Acute studies on animals (Muschaweck and Hajdú, 1964) and clinical trials of frusemide treatment continued for several months (Kleinfelder, 1963 ; Stokes and Nunn, 1964 ; Verel et al., 1964) have failed to demonstrate any toxic effects from ordinary doses of frusemide. Frusemide appears to have no diabetogenic action (Schaefer, 1964). Single doses of frusemide increase urate clearance (Schirmeister and Willmann, 1964), but it is not known whether prolonged treatment with frusemide, as with benzothiadiazine diuretics, will cause hyperuricaemia. The present trial was not designed to show up any toxic effects other than acute intolerance, and indeed the only disturbance which occurred after frusemide was occasional mild gastric discomfort. Hypersensitivity reactions to the drug may well occur. Though they are likely to be infrequent, no reliable estimate of the incidence and severity of such reactions will be possible until the drug has been used much longer. Since frusemide and its degradation products are excreted through the intestine as well as by the kidneys (Häussler and Hajdú, 1964), there is no contraindication to its repeated administration to patients with renal impairment.

\section{Summary}

Frusemide, a new orally effective diuretic, was compared for natriuretic effect with ethacrynic acid, bendrofluazide, and mersalyl in 11 patients with resistant oedema. The doses of frusemide used ranged from 20 to $240 \mathrm{mg}$. daily. Ethacrynic acid was given in daily doses of 100 or $200 \mathrm{mg}$., bendrofluazide in doses of $10 \mathrm{mg}$., and mersalyl in doses of $2 \mathrm{ml}$. Daily urinary volume and electrolyte excretion and change in weight were determined during successive treatment periods in which the order of drug administration was randomized.

Frusemide in doses of $200 \mathrm{mg}$. is much more potent than maximally effective doses of either bendrofluazide or mersalyl. Its potency is similar to that of ethacrynic acid when the two drugs are given in equal doses. The maximally effective dose of frusemide in oedematous patients is probably greater than $240 \mathrm{mg}$.

Frusemide and ethacrynic acid cause less urinary potassium excretion and a higher urinary sodium/potassium ratio than does bendrofluazide.

Resistance to frusemide may occur in patients with renal impairment or gross oedema ; in the latter case the addition of spironolactone may enhance diuresis.

The frusemide (Lasix) used in this trial was generously supplied by Hoechst Pharmaceuticals Pty. Ltd., Melbourne, and the ethacrynic acid by Merck Sharp and Dohme (Aust.) Pty. Ltd. Several of the patients included in the trial were referred for treatment by Dr. G. E. Bauer, who co-operated closely in the study. The urinary electrolyte determinations were performed by Miss Gillian Peart.

\section{RBPERENCES}

Cannon, P. J., Ames, R. P., and Laragh, J. H. (1963). F. Amer. med.

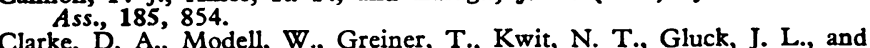
Gold, H.' (1950). Amer. F. med. Sci., 220, 156 . (1964). Med. Res., Edwards, $K$.

and Whyte, H. M. (1958). Aust. F. exp. Biol. med. Sci., 36, 383. Foltz, E. L. (1963). Fed. Proc., 22, 598.

Ford, R. V., and Nickell, J. (1960). Amer. Heart 7., 59, 215.

Gold, H., K̈wit, N. T., Messeloff, C. R., Kramer, M̈. L., Golfins, A. J., Greiner, T. H., Goessel, E. A., Hughes, J. H., and Warshaw, L. (1960).' F. Amer. med. Ass., 173, 745. 
Häussler, A., and Hajdú, P. (1964). Arzneimittel-Forsch., 14, 710. Heidland, A, Klürsch, K., and Suzuki, F. (1964). Ibid., 14, 713.

Kleinfelder, H. (1963). Disch. med. W schr., 88, 1695.

Maher, J. F., O'Cunnell, J. M. B., Setter, J. G., and Schreiner, G. E. (1964). "Clin. Res., 12, 70 .

Melvin, K. E. W., Farrelly, R. O., and North, J. D. K. (1963). Brit. med. j., i, 15 żi.

Muschaweck, R., and Haidú, P. (1964). Arzneimittel-Forsch., 14, 44.

Reubi, F. C., and Cottier, P. T. (1961). Circulation, 23, 200

Rosenkranz, A. (1964). Wien. med. W schr., 114, 236.

Schaefer, H.-F. (1964). Med. Welt (Stuttg.), 1, 922.
Schirmeister, J., and Willmann, H. (1964). Klin. Wschr., 42, 623.

Stewart, J. H. (1965). Submitted for publication.

Stokes, W., and Nunn, L. C. A. (1964). Brit. med. 7., 2,910 Suzuki, F., Klütsch, K., and Heidland, A. (1964). Klin. W schr., 42, 569.
Swartz, C., Seller, R., Fuchs, M., Brest, A. N., and Moyer, J. H. (1963). Circulation, 28, 1042

Timmerman, R. J., Springman, F. R., and Thoms, R. K. (1964). Curr. ther. Res., 6, 88.

Verel, D., Stentiford, N. H., Rahman, F., and Saynor, R. (1964). Lancet,

Vorburger, C. (1964). Rev. méd. Suisse rom., 84, 277.

\title{
Indomethacin and Phenylbutazone : a Comparison
}

\author{
F. DUDLEY HART,* M.D., F.R.C.P.; P. L. BOARDMAN,* M.R.C.P.
}

Brit. med. F., 1965, 2, 1281-1284

Early papers on indomethacin reported promising results from its use as a non-specific anti-inflammatory agent in the treatment of the chronic rheumatic disorders (Paul and Strottman, 1963 ; Ballabio et al., 1963), with dramatic results in gout (Smyth et al., 1963). A controlled clinical trial demonstrated significant preference for indomethacin against placebo in rheumatoid arthritis (Dixon et al., 1963). Measurable reduction of joint swelling as a result of treatment with indomethacin was reported in active rheumatoid arthritis (Hart and Boardman, 1964). There was no significant direrence between indomethacin and phenylbutazone (Percy et al., 1963)-in this trial the treatment period on each drug was one week and the indomethacin used was in tablet form, which, for various reasons, has been replaced by a gelatin-coated capsule.

This paper reports the results of a double-blind trial in which the effect of phenylbutazone is compared with that of indomethacin capsules, each drug being given for one month to patients with active rheumatoid arthritis. A brief account is also given of the results obtained from the treatment of rheumatoid arthritis, osteoarthritis, and ankylosing spondylitis with indomethacin during a period of two and a half years.

\section{Double-blind Trial}

All 26 patients who took part in the double-blind trial of indomethacin and phenylbutazone had classical rheumatoid arthritis or definite rheumatoid arthritis as defined by a Committee of the American Rheumatism Association (1959). The diagnosis of the classical form of the disease is applied to those patients in whom 7 out of the 11 criteria listed by the A.R.A. are present. A diagnosis of "definite" requires the presence of five of the criteria. Phenylbutazone, $100 \mathrm{mg}$. three times a day, was given to 13 patients in the first month, and indomethacin, $25 \mathrm{mg}$. three times a day, to 13 , therapy being changed to the other agent at the end of the month. To provide double-blind conditions they received active indomethacin and dummy phenylbutazone in one month, and in the other active phenylbutazone and dummy indomethacin. The group who started on indomethacin had a mean age of 47.6 years ; five were males and eight females. The mean duration of disease was 6.7 years. The patients who received phenylbutazone in the first month had a mean age of 48.8 years, an average length of history of 6.2 years, and there were four males and nine females. There were six patients with classical and seven with definite rheumatoid arthritis in each group. These patients were assessed by their own daily record of pain, stiffness, and loosening-up time, and the measurement of joint tenderness, joint swelling,

* Westminster Hospital, London. and grip strength at each visit (Hart and Boardman, 1963). All were attending the out-patient clinic at monthly intervals. They were assessed at the start of treatment and at the end of each trial period of 28 days. Their personal opinion as to the more satisfactory treatment period was recorded at the end of the trial.

\section{Results}

When asked at the end of the trial, before the identification of the specific treatment periods, which month was the more satisfactory, 15 patients preferred phenylbutazone, 10 found them to be equally effective, and one preferred indomethacin. This difference is statistically significant $(P<0.001)$.

A comparison of the pain record of each patient in the month on phenylbutazone with that of those on indomethacin revealed that this parameter improved selectively in five in phenylbutazone and in two on indomethacin, 19 finding no difference. A clinically significant alteration of pain was taken to be $25 \%$ or more in the month. Likewise, assuming a $25 \%$ difference to be significant, five were less stiff during phenylbutazone therapy and one on indomethacin, 20 finding no detectable difference. There is obviously no significant difference in these symptoms between the two groups.

An alteration in the duration of early-morning stiffness was assumed to be of clinical significance if it exceeded 30 minutes. In the first month, on phenylbutazone, there was improvement in the loosening-up time in seven patients and deterioration in one, five being unchanged. On indomethacin there was improvement in three, deterioration in four, and no change in six. These changes are not statistically significant $\left(x^{2}=1.4\right.$; $\mathrm{n}=1 ; 0.3>\mathrm{P}>0.2)$. In the second month, on indomethacin, improvement occurred in three patients, and this parameter worsened in two, eight exhibiting no change. On phenylbutazone there was no change in six, four improved, and three deteriorated.

A difference in grip strength of $50 \mathrm{~mm}$. of mercury was assumed to be clinically significant. In the first month, on phenylbutazone, none improved, five deteriorated, and eight remained unchanged. On indomethacin three improved, one deteriorated, and there was no change in nine. There was no statistically significant difference between the groups $\left(x^{2}=1.5\right.$; $\mathrm{n}=1 ; 0.3>\mathrm{P}>0.2)$. In the second month, on indomethacin, 11 patients remained unchanged, one improving, and one deteriorating. In comparison, on phenylbutazone, there was no change in 10 patients, improvement occurring in three. There was obviously no significant difference.

As 17 of the 26 patients had no tender joints at any time during the trial this was an unsatisfactory parameter. 